\title{
ANALISIS TINGKAT KECERNAAN PAKAN DAN LIMBAH NITROGEN (N) BUDIDAYA IKAN BANDENG SERTA KEBUTUHAN PENAMBAHAN C- ORGANIK UNTUK PENUMBUHAN BAKTERI HETEROTROF (BIOFLOK)
}

\author{
Usman", Neltje Nobertine Palinggi", Enang Harris"*), Dedi Jusadi" \\ Eddy Supriyono*), dan Munti Yuhana*") \\ *) Balai Riset Perikanan Budidaya Air Payau \\ Jl. Makmur Dg. Sitakka No. 129, Maros, Sulawesi Selatan 90511 \\ E-mail: siganus007@yahoo.com \\ *) Fakultas Perikanan dan Ilmu Kelautan, Institut Pertanian Bogor \\ Jl. Lingkar Kampus, Kampus IPB Darmaga, Bogor 16680
}

(Naskah diterima: 22 Agustus 2010; Disetujui publikasi: 12 Oktober 2010)

\begin{abstract}
ABSTRAK
Penelitian ini dilakukan untuk menganalisis kecernaan pakan dan beban limbah nitrogen $(\mathrm{N})$ dan karbon organik $(\mathrm{C})$ pada pembesaran ikan bandeng untuk dijadikan acuan penumbuhan bakteri heterotrof (bioflok). Pakan uji yang digunakan adalah pakan komersial yang memiliki kadar protein berbeda yaitu 17\%, $21 \%$, dan $26 \%$. Pakan tersebut digiling ulang, lalu ditambahkan kromium oksida $\left(\mathrm{Cr}_{2} \mathrm{O}_{3}\right)$ sebagai indikator kecernaan. Untuk menentukan total limbah $\mathrm{N}$ termasuk ekskresi amonia, dilakukan juga pemeliharaan ikan bandeng selama 45 hari dan menghitung retensi $\mathrm{N}$. Hasil penelitian menunjukkan bahwa kecernaan ketiga pakan tersebut tidak berbeda nyata yaitu antara 77,2\%-78,2\% untuk bahan kering; 88,6\%-90,0\% untuk protein; dan 81,6\%-83,1\% untuk $\mathrm{C}$-organik. Namun total limbah $\mathrm{N}$ per $100 \mathrm{~g}$ pakan yang masuk ke perairan meningkat secara nyata dengan meningkatnya kadar protein pakan yaitu 2,27 g N untuk pakan berprotein 17\%; 2,76 g N untuk pakan berprotein 21\%; dan 3,28 g N untuk pakan berprotein 26\%. Untuk mengkonversi limbah $\mathrm{N}$ dari budidaya bandeng ini menjadi bakteri heterotrof (bioflok), diperlukan aplikasi C-organik sebanyak $22,7 \mathrm{~g} ; 27,6$; dan $33 \mathrm{~g}$ per $100 \mathrm{~g}$ pakan berturut-turut untuk pakan yang berprotein $17 \%, 21 \%$, dan $26 \%$.
\end{abstract}

KATA KUNCl: kecernaan pakan, limbah N, ikan bandeng, dan bakteri heterotrof

ABSTRACT: Analysis of feed apparent digestibility coefficient and nitrogen waste of milk fish, and assessment of organic-C additional to promote heterotrophic bacteria. By: Usman, Neltje Nobertine Palinggi, Enang Harris, Dedi Jusadi, Eddy Supriyono, and Munti Yuhana

This experiment was conducted to analyze the feed digestibility and nitrogen $(N)$ waste of milk fish grow-out and assessment of organic-C addition to promote heterotrophic bacteria (biofloc). The three commercial diets were used containing different protein levels i.e. (A) $17 \%$, (B) $21 \%$, and (C) $26 \%$. Chromic oxide was used as the digestibility marker. To assess the total nitrogen waste, the milk fish with initial weight of $48 \mathrm{~g} /$ fish were reared for 45 days and the protein retention was calculated. The results showed that the apparent digestibility of the all three tested diets was not significantly different (>0.05) i.e. $77.2 \%-78.2 \%$ for dry matter, $88.6 \%-90 \%$ for protein, and $81.6 \%-83.1 \%$ for organic-C. However, the total nitrogen waste per $100 \mathrm{~g}$ 
of feed released to the waters tended to increase with the increase of protein content of the feed, i.e. $2.27 \mathrm{~g} \mathrm{~N}$ for $17 \%$ of diet protein content; $2.76 \mathrm{~g} \mathrm{~N}$ for $21 \%$ of diet protein content, and $3.28 \mathrm{~g} \mathrm{~N}$ for $26 \%$ of diet protein content. Conversion of the total $\mathrm{N}$ waste of milk fish grow-out to promote heterotrophic bacteria needed additional organic- $C$ of $22.7 \mathrm{~g} ; 27.6 \mathrm{~g} ; 33 \mathrm{~g}$ per $100 \mathrm{~g}$ of feed which have $17 \%, 21 \%$, and $26 \%$ protein contents.

\section{KEYWORDS: feed digestibility, $\mathrm{N}$ waste, milk fish, and heterotrophic bacteria}

\section{PENDAHULUAN}

Umumnya ikan membutuhkan protein pakan yang tinggi untuk tumbuh secara optimum, karena protein pakan selain digunakan sebagai zat penyusun tubuh (pertumbuhan) juga digunakan sebagai sumber energi (Wilson, 2002). Berbeda dengan hewan darat, ikan menggunakan protein secara efektif sebagai sumber energi utama dibandingkan karbohidrat dan lemak (Furuichi, 1988). Oleh karena itu, ikan banyak mengeluarkan limbah $\mathrm{N}$, utamanya amoniak $\left(\mathrm{NH}_{3}\right)$ sebagai hasil perombakan protein dan asam amino (deaminasi) untuk keperluan metabolismenya (sumber energi) (Halver \& Hardy, 2002). Selain itu, limbah $\mathrm{N}$ ini juga berasal dari sisa pakan yang tidak termakan dan feses. Menurut Avnimelech \& Ritvo (2003), jumlah N yang diretensi oleh ikan dari pakan yang diberikan hanya sekitar $20 \% 30 \%$ atau ratarata $25 \%$ dan sisanya sekitar $70 \%-80 \%$ baik berupa $\mathrm{N}$-organik maupun $\mathrm{N}$-anorganik dibuang ke perairan. Limbah organik dari pakan yang masuk perairan tersebut berupa sisa pakan dan partikel terlarut dalam air yang dapat mencapai $15 \%$ serta feses ikan sekitar 20\% (Montoya \& Velasco, 2000). Hal ini merupakan penyebab rendahnya efisiensi protein dan tingginya limbah $\mathrm{N}$ dari kegiatan budidaya intensif. Limbah $\mathrm{NH}_{3}$ dan turunannya $\mathrm{NO}_{2}$ memiliki sifat yang sangat toksik terhadap kehidupan ikan budidaya (Wedemeyer, 1996), sehingga harus diupayakan agar senyawa ini selalu dalam konsentrasi rendah yang tidak membahayakan kehidupan ikan budidaya. Oleh karena itu, perlu dicari upaya yang dapat meningkatkan efisiensi penggunaan protein pakan dan menurunkan beban limbah dari kegiatan budidaya ikan secara intensif, agar didapatkan kegiatan budidaya ikan dengan produktivitas tinggi dan berkesinambungan (Midelan \& Redding, 2000).

Bakteri heterotrof ternyata dapat mengasimilasi dengan cepat total amoniak (TAN) dalam perairan dan dikonversi menjadi protein bakteri jika terdapat keseimbangan $\mathrm{C} / \mathrm{N}$ yang optimal untuk pertumbuhannya yaitu antara 10-30 (Avnimelech, 1999; Montoya \& Velasco, 2000; Mclntosh, 2001; Brune et al., 2003; De Schryver et al., 2008). Pada budidaya ikan intensif dengan pemberian pakan buatan yang mengandung protein relatif tinggi menyebabkan $\mathrm{C} / \mathrm{N}$ rasio dalam media budidaya rendah $(<10)$, sehingga untuk menumbuhkan bakteri heterotrof ini diperlukan penambahan C-organik secara berkala. Jika bakteri heterotrof ini berkembang hingga kepadatan tertentu (8 $\left.10^{7} \mathrm{cfu} / \mathrm{mL}\right)$, maka akan membentuk bioflok. Bioflok ini merupakan campuran heterogen dari mikroba (bakteri, plankton, fungi, protozoa, ciliata, nematoda), partikel, koloid, polimer organik, kation yang saling berintegrasi cukup baik dalam air untuk tetap bertahan dari agitasi (goncangan) air yang moderat (Jorand et al., 1995). Flok mikroba ini mengandung nutrisi seperti protein (19\%-58\%), lemak (2\%-39\%), karbohidrat (27\%-59\%), dan abu (2\%-17\%) yang cukup baik bagi ikan/udang budidaya (Verstraete et al., 2008, Crab et al., 2009). Oleh karena itu, keuntungan budidaya ikan dengan teknologi bioflok ini adalah dapat memperbaiki kualitas air, meningkatkan efisiensi protein pakan dan mengurangi limbah budidaya.

Namun tidak semua ikan dapat memanfaatkan bioflok ini sebagai makanan. Menurut Bagarinao (1994), ikan bandeng di alam memiliki preferensi makanan yang beragam, yaitu memakan zooplankton, diatom, bentos kecil, alga filamen, alga mat, dan detritus. Struktur tapis insang ikan bandeng yang panjang-panjang dan rapat memiliki fungsi sebagai penyaring mikroorganisme air (seperti plankton) dan juga memiliki epibrancheal organ yang berfungsi sebagai alat untuk memadatkan material yang dimakan sebelum ditelan (Huisman, 1987). Oleh karena itu, diduga ikan bandeng mampu memanfaatkan bioflok sebagai makanannya. Sebagai langkah 
awal dalam pemanfaatan bioflok dalam budidaya ikan bandeng, maka dilakukan penelitian tentang kecernaan nutrien pakan dan pendugaan limbah $\mathrm{N}$ pada budidaya ikan bandeng untuk dijadikan acuan dalam penumbuhan bioflok.

\section{BAHAN DAN METODE}

\section{Pengamatan Kecernaan Nutrien Pakan}

Pakan uji yang digunakan adalah pakan komersil yang memiliki kandungan protein dan karbohidrat berbeda berturut-turut (A) $17 \%$ dan $62 \%$, (B) $21 \%$ dan $56 \%$, serta (C) $26 \%$ dan $52 \%$, dengan komposisi proksimat seperti yang disajikan pada Tabel 1.

Pada uji kecernaan pakan, wadah percobaan yang digunakan berupa 9 tangki conical fibre glass bervolume $200 \mathrm{~L}$ yang dilengkapi dengan sistem aerasi dan pergantian. Ikan bandeng ukuran sekitar $50 \pm 2,7$ g ditebar dengan kepadatan 15 ekor/tangki. Pakan uji tersebut digiling ulang, lalu ditambahkan kromium oksida $\left(\mathrm{Cr}_{2} \mathrm{O}_{3}\right)$ sebagai indikator masing-masing sebanyak 0,70\% (Furuichi, 1988). Ikan diberi pakan uji secara satiasi per hari dengan frekuensi 2 kali sehari pada pagi dan sore hari. Beberapa saat setelah pemberian pakan, air dikeluarkan untuk membuang sisa pakan yang ada dengan membuka kran bagian bawah. Sebelum pengambilan feses, ikan diadaptasikan dengan pakan uji tersebut selama 1 minggu, lalu pengumpulan feses dilakukan setiap tiga jam, untuk mencegah terjadi leaching nutrien pada feses. Feses yang terkumpul secepatnya disimpan dalam freezer hingga cukup untuk analisis kemudian dikeringkan dengan freezedried. Pada analisis proksimat pakan dan feses, sampel yang representative dianalisis berdasarkan metode AOAC International (1999): bahan kering (DM) dikeringkan dengan oven pada suhu $105^{\circ} \mathrm{C}$ selama 16 jam, serat kasar dengan ekstraksi ether, abu dengan pembakaran dalam muffle furnace pada suhu $550^{\circ} \mathrm{C}$ selama 24 jam dan protein kasar dianalisis dengan mikro-Kjeldahl, lemak dideterminasi secara gravimetrik dengan ekstraksi kloroform: methanol pada sampel. Kadar kromium dalam sampel pakan dan feses dianalisis berdasarkan prosedur Takeuchi (1988). Koefisien kecernaan bahan kering, protein, lemak, dan BETN (bahan ekstrak tanpa nitrogen) dan C-organik dari pakan uji dihitung dengan rumus (Takeuchi, 1988):

$$
\operatorname{ADC}(\%)=100 \times 1-\left[\frac{M_{D} \times A_{F}}{M_{F} \times A_{D}}\right]
$$

di mana:

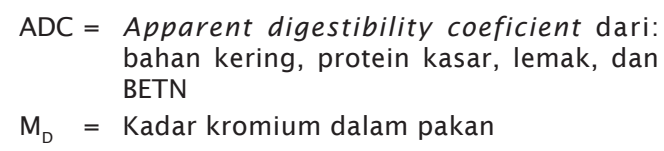

Tabel 1. Komposisi proksimat pakan uji (komersil) ikan bandeng (bobot kering) *

Table 1. Proximate composition of tested (commercial) diets (dry matter)

\begin{tabular}{|c|c|c|c|c|c|c|c|c|c|}
\hline \multirow[b]{2}{*}{$\begin{array}{l}\text { Jenis } \\
\text { pakan } \\
\text { Kind of } \\
\text { test } \\
\text { diets }\end{array}$} & \multicolumn{9}{|c|}{$\begin{array}{l}\text { Nutrien } \\
\text { Nutrients }\end{array}$} \\
\hline & $\begin{array}{c}\text { Air } \\
\text { Moist ure } \\
\text { (\%) }\end{array}$ & $\begin{array}{l}\text { Protein } \\
\text { kasar } \\
\text { Crude } \\
\text { protein } \\
\text { (\%) }\end{array}$ & $\begin{array}{c}\text { Lemak } \\
\text { kasar } \\
\text { Crude } \\
\text { lipid } \\
\text { (\%) }\end{array}$ & $\begin{array}{l}\text { Serat } \\
\text { kasar } \\
\text { Crude } \\
\text { fibre } \\
\text { (\%) }\end{array}$ & $\begin{array}{l}\text { Abu } \\
\text { Ash } \\
\text { (\%) }\end{array}$ & $\begin{array}{l}\text { BETN } \\
\text { NFE }\end{array}$ & $\begin{array}{c}\text { Total } \\
\text { energi } \\
\text { Energy } \\
\text { total } \\
(\text { kkal/kg) }\end{array}$ & $\begin{array}{c}\text { C-organik } \\
\text { Organic } \\
\text { C } \\
(\%)\end{array}$ & $\mathrm{C} / \mathrm{N}$ \\
\hline A & 8.30 & 17.3 & 5.0 & 7.9 & 7.5 & 62.4 & 4,013 & 51.50 & 18.6 \\
\hline B & 9.12 & 21.5 & 6.6 & 7.7 & 7.9 & 56.3 & 4,150 & 50.36 & 14.6 \\
\hline C & 8.39 & 25.9 & 6.1 & 5.8 & 9.8 & 52.5 & 4,194 & 50.74 & 12.3 \\
\hline
\end{tabular}

Kecuali air, semua fraksi dinyatakan dalam bobot kering (Except water, all fraction in dry matter)

** BETN (Bahan Ekstrak Tanpa Nitrogen)/NFE (Nitrogen Free Extract)

*** Dihitung berdasarkan nilai koefisien energi untuk protein, lemak, dan BETN berturut-turut adalah 5,$64 ; 9,44 ;$ dan $4,11 \mathrm{kkal} / \mathrm{g}$ (Calculated based on the determined protein, lipid and NFE of the diet using gross energy convertion coefficients of $5.64,9.44$, and $4.11 \mathrm{kcal} / \mathrm{g}$ respectively (National Research Council, 1993) 
$\mathrm{M}_{\mathrm{F}}=$ Kadar kromium dalam feses

$A_{D}=$ Kadar nutrien dalam pakan

$A_{F}=$ Kadar nutrien dalam feses

\section{Pengamatan Pertumbuhan dan Retensi Protein}

Wadah percobaan yang digunakan berupa 9 tangki fibre glass bervolume $200 \mathrm{~L}$ yang dilengkapi dengan sistem aerasi dan pergantian air. Ikan bandeng ukuran sekitar $48,4 \pm 6,4 \mathrm{~g}$ akan ditebar dengan kepadatan 10 ekor/tangki. Pakan uji yang digunakan adalah pakan komersil yang memiliki kadar protein berbeda yaitu $17 \%, 21 \%$, dan $26 \%$. Pakan uji diberi sebanyak 3\%/hari pada pagi dan sore hari selama 45 hari. Sisa pakan dikeluarkan sesaat setelah pemberian pakan, dikumpulkan, dikeringkan, dan dicatat.

Pada awal dan akhir percobaan dilakukan pengukuran bobot ikan, dan jumlah pakan yang terkonsumsi dihitung untuk menentukan retensi protein. Pada awal percobaan, ikan diambil sebanyak 3 ekor, dan pada akhir percobaan juga diambil masing-masing 3 ekor dari setiap unit bak. Ikan tersebut dimatikan, lalu dicincang dan digiling, kemudian dikeringkan dalam fresh dryer untuk selanjutnya dianalisis komposisi proksimat tubuhnya. Performansi pertumbuhan ikan dan retensi protein dihitung dengan rumus sebagai berikut:

Laju pertumbuhan spesifik (SGR) ikan berdasarkan formulasi berikut (Schulz et al., 2005):

$$
\text { SGR }(\% \text { per hari })=100 \times \frac{\operatorname{lnW}_{e}-\ln W_{s}}{d}
$$

di mana:

In adalah logaritma alamiah, $W_{e}$ dan $W_{s}$ berturut-turut adalah bobot ikan pada akhir dan awal penelitian, dan d adalah jumlah hari pemeliharaan

Efisiensi pakan $=$ Pertambahan bobot biomassa (bobot basah) / bobot konsumsi pakan (bobot kering) (Takeuchi, 1988)

Retensi protein $(\%)=100 \times$ pertambahan protein ikan (g) / jumlah konsumsi protein (g)\} (Takeuchi, 1988)

Rasio efisiensi protein, PER = Pertambahan bobot ikan (g) / Jumlah protein yang dimakan (g) (Hardy, 1989)
Sintasan ikan, SR (\%) = (Jumlah ikan akhir penelitian / Jumlah ikan awal penelitian) $x$ 100

\section{Analisis Statistik}

Hasil pengukuran kecernaan total bahan kering, protein, lemak, BETN, dan C-organik pakan serta retensi protein dianalisis ragam. Jika terdapat perbedaan yang nyata di antara perlakuan, maka dilanjutkan dengan uji nilai tengah Tukey (Steel \& Torrie, 1995).

\section{HASIL DAN BAHASAN}

\section{Kecernaan Pakan}

Hasil pengamatan nilai kecernaan nutrien pakan ikan bandeng yang digunakan dalam percobaan ini disajikan pada Tabel 2. Pada Tabel 2, terlihat bahwa nilai kecernaan bahan kering, protein, lemak, BETN, dan C-organik pakan cukup tinggi untuk semua jenis pakan. Hasil analisis statistik menunjukkan bahwa nilai kecernaan nutrien pakan tersebut berbeda tidak nyata $(P>0,05)$ untuk peubah yang diamati. Hal ini menunjukkan bahwa persentase limbah padatan dari total jumlah pakan yang dikonsumsi oleh ikan bandeng relatif sama untuk semua jenis pakan tersebut. Namun demikian, karena kandungan protein dan karbohidrat pakan yang berbeda, maka jumlah protein dan karbohidrat pakan yang dikeluarkan ke lingkungan cenderung meningkat dengan meningkatnya jumlah protein dan karbohidrat pakan (Tabel 3). Hal ini mengindikasikan bahwa semakin tinggi kandungan protein pakan ikan bandeng ini, maka jumlah limbah nitrogen padatan dalam bentuk feses juga meningkat. Pada pakan yang mengandung protein sekitar 17,3\%; $21,5 \%$; dan $25,9 \%$, maka setiap 100 g pakan yang dikonsumsi oleh ikan bandeng akan menghasilkan limbah padatan protein berturutturut sekitar $2,0 \mathrm{~g} ; 2,2 \mathrm{~g}$; dan $2,6 \mathrm{~g}$ atau berurutturut sekitar 0,32;0,35 g dan 0,42 g N. Sementara jumlah C-organik dalam feses dari setiap $100 \mathrm{~g}$ pakan tersebut berturut-turut adalah 9,5 g; 9,2 g; dan $8,6 \mathrm{~g}$; sehingga rasio $\mathrm{C} / \mathrm{N}$ dalam feses ikan bandeng yang diberi pakan tersebut berturut-turut sekitar 29,7; 26,1 ; dan 20,7 . Rasio C/N dalam feses ikan bandeng tersebut cukup optimal untuk pertumbuhan bakteri heterotrof, jika terjadi dalam kondisi aerob (Montoya \& Velasco, 2000; Mclntosh, 2001; Avnimelech, 2009). 
Tabel 2. Koefisien kecernaan pakan komersil ikan bandeng yang mengandung kadar protein dan karbohidrat berbeda

Table 2. The apparent digestibility coefficients of milk fish commercial diets contain different protein and carbohydrate levels

\begin{tabular}{cccccc}
\hline \multirow{2}{*}{$\begin{array}{c}\text { Jenis pakan } \\
\text { Kind of tested } \\
\text { diets }\end{array}$} & \multicolumn{5}{c}{$\begin{array}{c}\text { Koefisien kecernaan } \\
\text { Apparent digest ibility coefficients (\%) }\end{array}$} \\
\cline { 2 - 6 } & $\begin{array}{c}\text { Bahan kering } \\
\text { Drymatter }\end{array}$ & $\begin{array}{c}\text { Protein kasar } \\
\text { Crude protein }\end{array}$ & $\begin{array}{c}\text { Lemak } \\
\text { Crude Lipid }\end{array}$ & $\begin{array}{c}\text { BETN } \\
\text { NFE }\end{array}$ & $\begin{array}{c}\text { C-organik } \\
\text { Organic C }\end{array}$ \\
\hline A & $77.2 \pm 2.4^{\mathrm{a}}$ & $88.6 \pm 0.7^{\mathrm{a}}$ & $94.2 \pm 1.7^{\mathrm{a}}$ & $80.5 \pm 2.8^{\mathrm{a}}$ & $81.6 \pm 1.9^{\mathrm{a}}$ \\
$\mathrm{B}$ & $78.2 \pm 3.2^{\mathrm{a}}$ & $89.7 \pm 2.3^{\mathrm{a}}$ & $95.8 \pm 0.9^{\mathrm{a}}$ & $81.3 \pm 2.6^{\mathrm{a}}$ & $81.7 \pm 2.7^{\mathrm{a}}$ \\
C & $77.7 \pm 5.0^{\mathrm{a}}$ & $90.0 \pm 1.8^{\mathrm{a}}$ & $96.1 \pm 1.0^{\mathrm{a}}$ & $80.8 \pm 6.1^{\mathrm{a}}$ & $83.1 \pm 3.8^{\mathrm{a}}$ \\
\hline
\end{tabular}

Nilai tengah dalam kolom yang sama diikuti superscript yang sama menunjukkan tidak berbeda nyata $(P>0,05)$.

Means in the same colom followed by the same superscript are not significantly different $(P>0.05)$

\section{Pertumbuhan Ikan dan Retensi Protein Pakan}

Hasil pengamatan tentang performansi pertumbuhan dan retensi protein pakan disajikan pada Tabel 3. Berdasarkan hasil tersebut menunjukkan bahwa bobot akhir dan laju pertumbuhan spesifik ikan, rasio konversi pakan dan rasio efisiensi protein berbeda nyata $(P<0,05)$ di antara perlakuan (pakan uji). Bobot akhir dan laju pertumbuhan spesifik ikan meningkat seiring dengan meningkatnya kadar protein pakan. Rasio konversi pakan juga menjadi lebih baik dengan meningkatnya kadar protein pakan. Namun efisiensi protein menurun dengan meningkatnya kadar protein pakan. Sementara retensi protein dan sintasan ikan relatif sama di antara semua pakan uji. Hal ini menunjukkan bahwa pada budidaya ikan bandeng dengan mengandalkan 100\% pakan buatan, maka menggunakan pakan yang mengandung protein sekitar $26 \%$ lebih baik dibandingkan dengan menggunakan pakan yang mengandung protein $21 \%$ dan $17 \%$ untuk mendapatkan pertumbuhan dan efisiensi pakan yang lebih tinggi.

Meskipun ikan bandeng yang diberi pakan dengan kadar protein tinggi (26\%) memiliki laju pertumbuhan dan efisiensi pakan yang lebih tinggi dibandingkan ikan yang diberi pakan berprotein lebih rendah, namun jumlah limbah $\mathrm{N}$-nya yang masuk ke perairan juga lebih tinggi. Agar limbah $\mathrm{N}$ ini tidak menjadi beban bagi lingkungan sekitarnya dan tidak mengganggu kehidupan ikan bandeng itu sendiri, maka perlu limbah ini dikelola dengan baik. Bahkan harus diupayakan agar limbah tersebut dapat dikonversi menjadi makanan kembali bagi ikan bandeng. Salah satu solusi yang memung-

Tabel 3. Jumlah nutrien yang dikeluarkan dalam bentul feses ikan dari setiap $100 \mathrm{~g}$ pakan (bahan kering) yang dikonsumsi oleh ikan bandeng

Table 3. Total nutrients excreted in form of milk fish feces from each $100 \mathrm{~g}$ consumed tested diets (dry matter)

\begin{tabular}{|c|c|c|c|c|c|}
\hline \multirow{2}{*}{$\begin{array}{l}\text { Jenis Pakan } \\
\text { Kind of test diets }\end{array}$} & \multicolumn{5}{|c|}{$\begin{array}{c}\text { Nutrien } \\
\text { Nutrients (g) }\end{array}$} \\
\hline & $\begin{array}{c}\text { Bahan kering } \\
\text { Drymatter }\end{array}$ & $\begin{array}{l}\text { Protein kasar } \\
\text { Crude prot ein }\end{array}$ & $\begin{array}{c}\text { Lemak } \\
\text { Crude lipid }\end{array}$ & $\begin{array}{l}\text { BETN } \\
\text { NFE }\end{array}$ & $\begin{array}{l}\text { C-organik } \\
\text { Organic C }\end{array}$ \\
\hline A & 22.8 & 2.0 & 0.3 & 12.2 & 9.5 \\
\hline B & 21.8 & 2.2 & 0.3 & 10.5 & 9.2 \\
\hline C & 22.3 & 2.6 & 0.2 & 10.1 & 8.6 \\
\hline
\end{tabular}


Table 4. Performansi pertumbuhan ikan dan retensi protein pakan uji

Table 4. Growth performance of milk fish and protein retention of teste diets

\begin{tabular}{|c|c|c|c|}
\hline \multirow{2}{*}{$\begin{array}{l}\text { Peubah } \\
\text { Variables }\end{array}$} & \multicolumn{3}{|c|}{$\begin{array}{l}\text { Pakan uji } \\
\text { Tested diets }\end{array}$} \\
\hline & A & B & C \\
\hline $\begin{array}{l}\text { Laju pertumbuhan spe sifik ikan } \\
\text { Specific growth rate (\%/day) }\end{array}$ & $0.60 \pm 0.02^{\mathrm{a}}$ & $0.69 \pm 0.02^{b}$ & $0.75 \pm 0.03^{c}$ \\
\hline $\begin{array}{l}\text { Efisiensi pakan } \\
\text { Feed efficiency }\end{array}$ & $0.25 \pm 0.01^{\mathrm{a}}$ & $0.30 \pm 0.01^{b}$ & $0.32 \pm 0.02^{c}$ \\
\hline $\begin{array}{l}\text { Rasio efisiensi prote in } \\
\text { Protein efficiency ratio }\end{array}$ & $1.45 \pm 0.04^{\mathrm{a}}$ & $1.38 \pm 0.05^{b}$ & $1.25 \pm 0.07^{c}$ \\
\hline $\begin{array}{l}\text { Retensi protein } \\
\text { Protein retention (\%) }\end{array}$ & $17.75 \pm 3.10^{a}$ & $20.07 \pm 3.01^{\mathrm{a}}$ & $20.65 \pm 2.08$ \\
\hline $\begin{array}{l}\text { Sintasan } \\
\text { Survival rate (\%) }\end{array}$ & $100 \pm 0.0^{\mathrm{a}}$ & $96.7 \pm 5.8^{a}$ & $100 \pm 0.0^{a}$ \\
\hline $\begin{array}{l}\text { Total } \mathrm{N} \text { pakan }(\mathrm{g}) \text { masuk ke dalam } \\
\text { media budidaya per } 100 \mathrm{~g} \text { pakan } \\
\text { Total loading of } \mathrm{N} \text {-diets }(\mathrm{g}) \text { to } \\
\text { environment for } 100 \mathrm{~g} \text { diets }\end{array}$ & $2.27 \pm 0.09^{a}$ & $2.76 \pm 0.11^{\mathrm{b}}$ & $3.28 \pm 0.09^{c}$ \\
\hline
\end{tabular}

Nilai tengah dalam baris yang sama diikuti superscript yang sama menunjukkan tidak berbeda nyata $(P>0,05)$

Means in the same row followed by the same superscript are not significantly different $(P>0.05)$

kinkan untuk hal tersebut adalah mengkonversi limbah ikan bandeng tersebut menjadi protein bakteri (bioflok). Bioflok ini telah terbukti dapat dimanfaakan oleh beberapa jenis ikan budidaya seperti ikan nila, udang vaname, dan udang galah (Avnimelech, 1999, 2009; Brune et al., 2003; Crab et al., 2009). Mikroorganisme yang dapat mengkonversi TAN dengan cepat menjadi protein dan menjadi inisiator pembentuk bioflok dalam media budidaya adalah bakteri heterotrof. Bakteri ini menyebar dalam kolom air dan permukaan sedimen serta memiliki kemampuan pertumbuhan populasi yang lebih cepat dibandingkan fitoplankton dan bakteri nitrifikasi bila terjadi rasio $\mathrm{C} / \mathrm{N}$ dalam media budidaya sekitar 10-30 (Avnimelech, 1999; Montoya \& Velasco, 2000; Brune et al., 2003). Namun dalam budidaya ikan bandeng intensif ini, protein pakan banyak digunakan oleh ikan sebagai sumber energi, sehingga kandungan limbah N utamanya Total Ammonia Nitrogen (TAN) dalam media budidaya cukup tinggi, terlebih pada budidaya dengan sistem zero water exchange. Oleh karena itu, untuk mempertahankan kondisi rasio $\mathrm{C} / \mathrm{N}$ dalam media budidaya ikan bandeng agar bakteri heterotrof dapat berkembang dan memicu terbentuknya bioflok, maka perlu ditambahkan C-organik.

Berdasarkan perhitungan yang dikembangkan oleh De Schryver et al. (2008) dengan data pada ikan bandeng untuk penumbuhan bakteri heterotrof (bioflok) dalam media budidayanya, dapat dijabarkan pada Gambar 1. Berdasarkan perhitungan tersebut, maka untuk mengasimilasi semua limbah $\mathrm{N}$ dari budidaya ikan bandeng intensif di tambak/ kolam atau di bak, maka dipelukan aplikasi C-organik minimal sebanyak 22,7; 27,6; dan $32,8 \mathrm{~g} / 100 \mathrm{~g}$ pakan/hari berturut-turut untuk pakan yang memiliki kandungan protein $17,3 \%$; $21,5 \%$; dan 25,9\%. Sementara jika memperhitungkan kandungan C-organik feses, maka untuk mengasimilasi semua limbah $\mathrm{N}$ diperlukan C-organik sebanyak 13,2; 18,4; dan $24,2 \mathrm{~g} /$ hari/100 g pakan berturut-turut yang mengandung protein $17,3 \% ; 21,5 \%$; dan $25,9 \%$. 


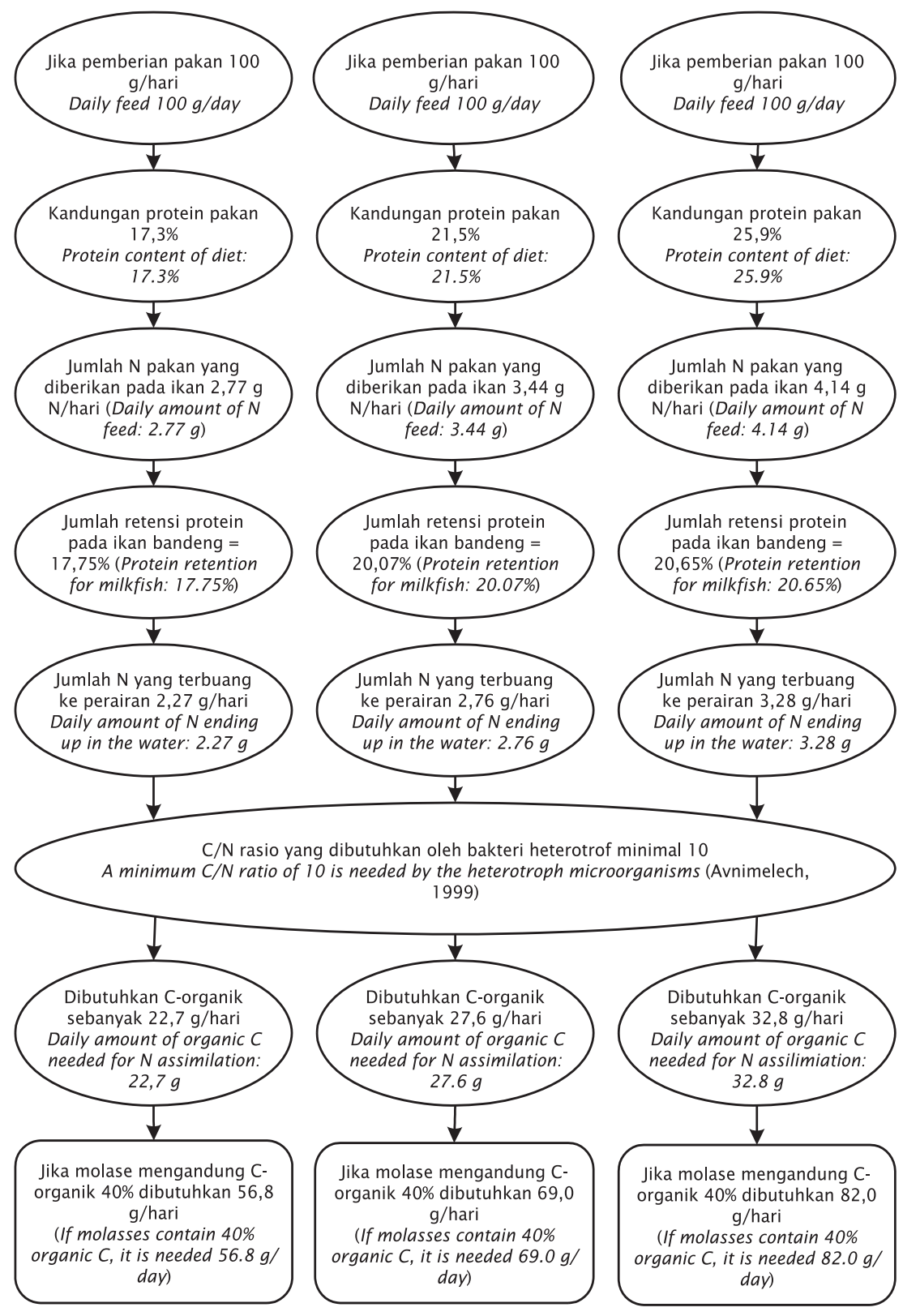

Gambar 1. Skema perhitungan jumlah penambahan C-organik menurut De Schryver et al. (2008), untuk mengasimilasi limbah $\mathrm{N}$ dalam penumbuhan bioflok pada budidaya ikan bandeng intensif di tambak/ kolam

Figure 1. Schematic calculation of the daily amount of organic carbon needed by bioflocs according to Des Schryver et al. (2008) to remove the nitrogen excreted in an intensif milkfish pond 


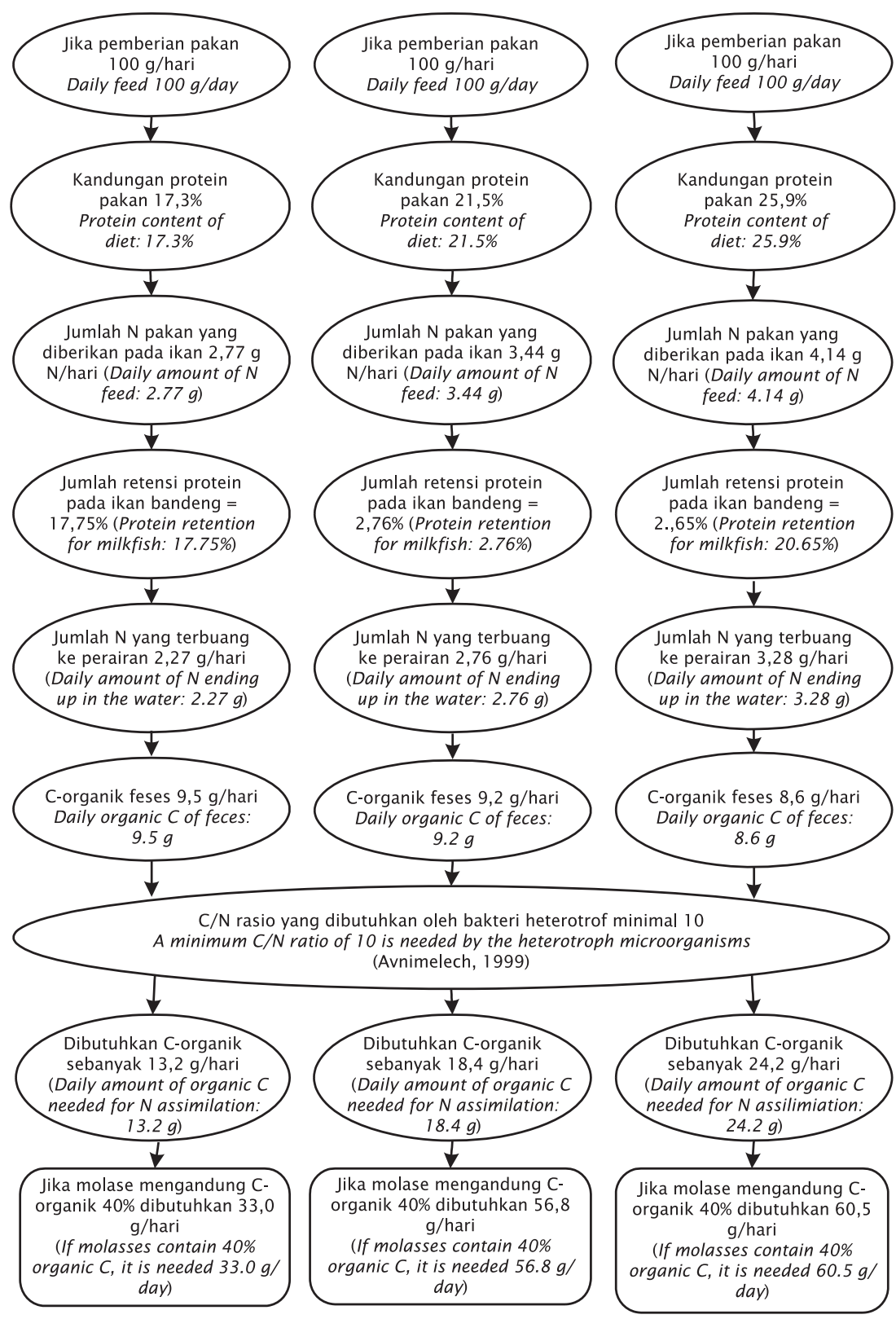

Gambar2. Skema perhitungan jumlah penambahan C-organik dengan memperhitungkan kandungan C-organik feses untuk mengassimilasi limbah $\mathrm{N}$ dalam penumbuhan bioflok pada budidaya ikan bandeng intensif di tambak/kolam

Figure 2. Schematic calculation of the daily amount of organic carbon needed by calculating organic $C$ of feces to remove the nitrogen excreted in an intensif milkfish pond 


\section{KESIMPULAN}

Berdasarkan hasil penelitian ini disimpulkan bahwa:

1. Tingkat kecernaan ketiga pakan tersebut relatif sama yaitu antara $77,2 \%-78,2 \%$ untuk bahan kering, $88,6 \%-90 \%$ untuk protein dan $81,6 \%-83,1 \%$ untuk C-organik.

2. Ikan yang diberi pakan dengan kandungan protein $26 \%$ memiliki laju pertumbuhan dan efisiensi pakan yang relatif lebih tinggi daripada yang diberi pakan dengan kandungan protein $21 \%$ atau $17 \%$.

3. Total limbah $\mathrm{N}$ per $100 \mathrm{~g}$ pakan yang masuk ke perairan meningkat dengan meningkatnya kadar protein pakan yaitu $2,27 \mathrm{~g} \mathrm{~N}$ untuk pakan berprotein $17 \% ; 2,76 \mathrm{~g} \mathrm{~N}$ untuk pakan berprotein $21 \%$, dan $3,28 \%$ untuk pakan berprotein 26\%. Untuk mengkonversi limbah $\mathrm{N}$ dari budidaya bandeng ini menjadi bakteri heterotrof (bioflok) diperlukan aplikasi C-organik minimal sebanyak 22,7; 27,6; dan 32,8 g/100 g pakan/hari berturut-turut untuk pakan yang memiliki kandungan protein 17,3\%; 21,5\%; dan 25,9\%. Sementara jika memperhitungkan kandungan C-organik feses, maka untuk mengasimilasi semua limbah $\mathrm{N}$ diperlukan C-organik minimal sebanyak 13,$2 ; 18,4$; dan 24,2 g/hari/100 g pakan berturut-turut yang mengandung protein $17,3 \% ; 21,5 \%$; dan $25,9 \%$.

\section{DAFTAR ACUAN}

AOAC (Association of Official Analytical Chemists) International. 1999. Official Methods of Analysis, $16^{\text {th }}$ edn. Gaithersberg, Maryland, USA, 1,141 pp.

Avnimelech, Y. 1999. Carbon/nitrogen ratio as a control element in aquaculture systems. Aquaculture, 176: 227-235.

Avnimelech, Y., \& Ritvo, G. 2003. Shrimp and fish pond soils: processes and management. Aquaculture, 220: 549-567.

Avnimelech, Y. 2009. Biofloc Technology. World Aquaculture Society, Louisiana, USA, $182 \mathrm{pp}$.

Bagarinao, T.U. 1994. Systematics, distribution, genetics and life history of milkfish, Chanos chanos. Environmental Biology of Fishes, 39: 23-41.

Brune, D.E., Schwartz, G., Eversole, A.G., Collier, J.A., \& Schwedler, T.E. 2003. Intensification of pond aquaculture and high rate photo- synthetic systems. Aquaculture Engineering, 28: 65-86.

Crab, R., Chielens, B., Wille, M., Bossier, P., \& Verstraete, W. 2009. The effect of different carbon sources on the nutritional value of bioflocs, a feed for Macrobrachium rosembergii postlarvae. Aquaculture Research, p. 1-9.

De Schryver, P., Crab, R., Defoirdt, T., Boon, N., $\&$ Verstraete, W. 2008. The basics of bioflocss technology: The added value for aquaculture. Aquaculture, 277: 125-137.

Furuichi, M. 1988. Dietary requirement. In: Watanabe, T (Ed.), Fish Nutrition and Mariculture. JICA Kanagawa International Fisheries Training Centre, Tokyo, p. 8-78.

Halver, J.E., \& Hardy, R.W. 2002. Nutrient flow and retention. In: Halver, J.E. \& Hardy, R.W. (Eds.). Fish Nutrition. Academic Press, New York, p. 755-770.

Hardy, R.W. 1989. Diet preparation. In Halver, J.E. (ed.). Fish Nutrition. Second Edition. Academic Press, Inc., San Diego, p. 476549.

Huisman, E.A. 1987. Principles of fish production. Department of Fish Culture and Fisheries, Wageningen Agricultural University, Wageningen, Netherlands, $170 \mathrm{pp}$.

Jorand, F., Zartarian, F., Thomas, F., Block, J.C., Betteru, J.V., Villemin, G., Urbain, V., \& Manen, J. 1995. Chemical and structural $\left(2^{\text {nd }}\right)$ linkage between bacteria within activated-sludge flock. Water Res., 29 (7): 1,639-1,647.

Mclntosh, R.P. 2001. Ghangin paradigms in shrimp farming: V. Establishment of heterotrophic bacterial communities. Global Aquaculture Advocate, p. 53-58.

Midelan, A., \& Redding, T. 2000. Environmental Management for Aquaculture. Kluwer Academic Publishers, Netherlands, 223 pp.

Montoya, R., \& Velasco, M. 2000. Role of bacteria on nutritional and management strategies in aquaculture systems. Global Aquaculture Advocate, 3(2): 35-36.

NRC (National Research Council). 1993. Nutrient requirement of fish. National Academy Press, Washington. D.C., 114 pp.

Schulz, C., Knaus, U., Wirth, M., \& Rennert, B. 2005. Effect of varying dietary fatty acid propile on growth performance, fatty acid, body and tissue composition of juvenile pike perch (Sander lucioperca). Aquaculture Nutrition, 11: 403-413. 
Steel, R.G.D. \& Torrie, J.H. 1995. Prinsip dan Prosedur Statistika. Alih bahasa: Bambang Sumantri. Gramedia Pusaka Utama, Jakarta, $748 \mathrm{hlm}$.

Takeuchi, T. 1988. Laboratory work-chemical evaluation of dietary nutrients. In: Watanabe, T. (ed.) Fish Nutrition and Mariculture. JICA Kanagawa International Fisheries Training Centre, Tokyo, p. 179-233.

Verstraete, W., Schryver, P.D., Defoirdt, T., \& Crab, R. 2008. Added value of microbial life in flock. Laboratory for Microbial Ecology and Technology, Ghent Univeristy, Belgium, 43 pp. http://labmet.ugent.be, 43 pp.

Wedemeyer, G.A. 1996. Physiology of fish in intensive culture systems. Chapman \& Hall. New York, 277 pp.

Wilson, R.P. 2002. Amino acids and proteins. In: Halver, J.E., \& Hardy, R.W. (Eds.) Fish Nutrition. New York: Academic Press, p. 143179. 